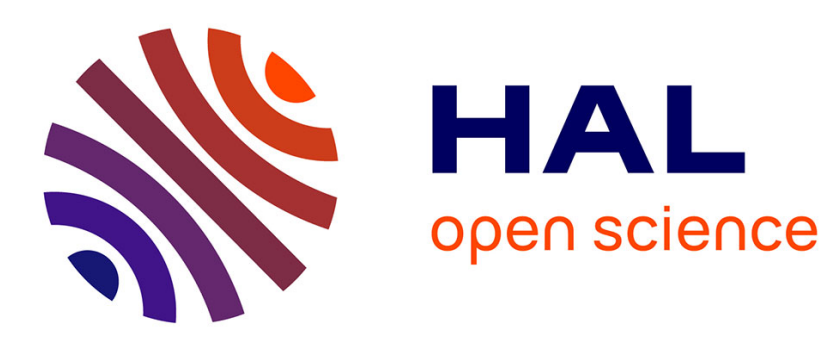

\title{
Susceptibilité du deuxième ordre et structure cristalline des iodates
}

\author{
G. Duraffourg, D.S. Chemla, J. Jerphagnon
}

\section{To cite this version:}

G. Duraffourg, D.S. Chemla, J. Jerphagnon. Susceptibilité du deuxième ordre et structure cristalline des iodates. Revue de Physique Appliquée, 1975, 10 (6), pp.363-363. 10.1051/rphysap:01975001006036300 . jpa-00243928

\section{HAL Id: jpa-00243928 https://hal.science/jpa-00243928}

Submitted on 1 Jan 1975

HAL is a multi-disciplinary open access archive for the deposit and dissemination of scientific research documents, whether they are published or not. The documents may come from teaching and research institutions in France or abroad, or from public or private research centers.
L'archive ouverte pluridisciplinaire HAL, est destinée au dépôt et à la diffusion de documents scientifiques de niveau recherche, publiés ou non, émanant des établissements d'enseignement et de recherche français ou étrangers, des laboratoires publics ou privés. 


\title{
SUSCEPTIBILITÉ DU DEUXIÈME ORDRE ET STRUCTURE CRISTALLINE DES IODATES
}

\author{
G. DURAFFOURG, D. S. CHEMLA, J. JERPHAGNON \\ Centre National d'Etudes des Télécommunications, 92220 Bagneux, France
}

\begin{abstract}
Résumé. - Dans l'étude des propriétés diélectriques des cristaux il est courant de faire l'hypothèse de l'additivité des polarisations microscopiques pour tenter d'obtenir les propriétés microscopiques (des liaisons chimiques par exemple) qui relèvent d'études théoriques, à partir des propriétés macroscopiques (susceptibilité du premier ou du deuxième ordre) qu'on peut mesurer. Ainsi on a étudié la susceptibilité du deuxième ordre (dans le cas de la génération de second harmonique) dans une série de cinq iodates $\left(\mathrm{HIO}_{3}, \mathrm{LiIO}_{3}, \mathrm{Ca}\left(\mathrm{IO}_{3}\right)_{2}, 6 \mathrm{H}_{2} \mathrm{O}, \mathrm{K}_{2} \mathrm{H}\left(\mathrm{IO}_{3}\right)_{2} \mathrm{Cl}, \mathrm{KIO}_{2} \mathrm{~F}_{2}\right)$, en supposant que les unités microscopiques (les liaisons chimiques) ont les mêmes propriétés dans toutes les substances.
\end{abstract}

On a utilisé le formalisme des tenseurs irréductibles, qui permet de disjoindre les équations relatives aux tenseurs de poids différents ; dans le cas de génération de second harmonique interviennent seulement un tenseur vectoriel et un tenseur septoriel.

Mieux que par l'analyse cartésienne classique, cette méthode permet de toucher du doigt les limites que la structure cristalline impose au choix de l'unité microscopique. Ainsi pour les quatre premiers iodates cités, la seule unité microscopique qu'on peut caractériser de façon sûre est l'octaèdre d'atomes d'oxygène entourant l'atome d'iode, idéalisé dans une symétrie $3 \mathrm{~m}$. On détermine sa polarisabilité du deuxième ordre par ses trois composantes indépendantes, une composante vectorielle $\beta_{333}+2 \beta_{311}=-20$, deux composantes septorielles $\beta_{333}-3 \beta_{311}=15$ et $\beta_{222}=2,6$ (valeurs exprimées en $10^{-28} \mathrm{~m}^{3} d_{123} \mathrm{KDP}$ ), qui conduisent à des susceptibilités macroscopiques en accord avec les valeurs expérimentales à $20 \%$ près en moyenne.

L'examen de la composante vectorielle montre comment l'orientation des octaèdres dans le cristal impose le signe des composantes de la susceptibilité macroscopique.

On rencontre de sérieuses difficultés lorsqu'on se livre à une analyse trop fine en voulant identifier les propriétés de chaque type de liaison comme ont tenté de le faire J. Bergman et al. [1]. Ces difficultés tiennent à ce que l'environnement des atomes d'iode varie trop peu d'une substance à l'autre. Cependant cette tentative montre la nécessité de prendre en compte la paire libre d'électrons complétant les liaisons de valence de l'iode et détermine sa composante septorielle $\left(\beta_{\|}-3 \beta_{\perp}\right)$ de façon à peu près sûre. Elle confirme aussi que pour les différents types de liaisons on ne peut pas négliger $\beta_{\perp}$ par rapport à $\beta_{\|}$, contrairement à ce qui se passe pour les composés à structure tétraédrique [2]

Abstract. - In studying dielectric properties of crystals, one usually assumes that microscopic polarizations are additive when trying to reach the microscopic properties (of chemical bonds for instance) relevant to theoretical studies, from the macroscopic ones (first or second order susceptibility) which can be obtained from experiment. Thus, second order susceptibility - in the case of second harmonic generation - of a five iodate series $\left(\mathrm{HIO}_{3}, \mathrm{LiIO}_{3}, \mathrm{Ca}\left(\mathrm{IO}_{3}\right)_{2}, 6 \mathrm{H}_{2} \mathrm{O}, \mathrm{K}_{2} \mathrm{H}\left(\mathrm{IO}_{3}\right)_{2} \mathrm{Cl}\right.$, $\mathrm{KIO}_{2} \mathrm{~F}_{2}$ ) has been investigated assuming that their microscopic properties (chemical bonds) are the same for any of the considered compounds.

The irreducible tensors formalism has been used, allowing a separation of the equations relative to the tensors with different weight ; in the case of second harmonic generation only a vector and a septor part appear.

This method emphasizes the limits assigned by the crystalline structure to the choice of the microscopic units much better than a classical cartesian analysis. It is shown that, for the first four mentioned iodates, the only microscopic unit which can be reliably characterized is the octahedron of oxygen atoms surrounding the iodine in an ideal $3 \mathrm{~m}$ symmetry. Its second order polarizability is determined by its three independent components, a vector part $\beta_{333}+2 \beta_{311}=-20$, two septor parts $\beta_{333}-3 \beta_{311}=15$ and $\beta_{222}=2.6$ (values in $10^{-28} \mathrm{~m}^{3} d_{123} \mathrm{KDP}$ units). This leads to macroscopic susceptibilities in agreement with experiment within an accuracy of $20 \%$.

A study of the vector components shows how the octahedra orientation in the crystal determines the sign of the macroscopic susceptibility components.

Very important difficulties are encountered if one tries to refine the analysis while identirying the properties of each type of bonding, as attempted by J. Bergman et al. [1]. These difficulties arise from the fact that the iodine atoms environment varies very little from a compound to another. However such an attempt shows how necessary it is to take into account the lone pair which completes the iodine valence bonds and determines its septor part $\left(\beta_{\|}-\beta_{\perp}\right)$ with a pretty good precision. It also confirms that $\beta_{\perp}$ ought not to be neglected with respect to $\beta_{\|}$, an hypothesis which is usually suitable for materials with tetrahedral structure [2].

\section{Bibliographie}

[1] Bergman, J. G., Crane, G. R., J. Chem. Phys. 60 (1974)

[2] Flytzanss, C., Ducuing, J., Phys. Rev. 178 (1969) 1218. 2470 . 